\title{
Molecular and Cellular Mechanisms Underlying Temperature-Dependent Sex Determination in Turtles
}

\author{
Horacio Merchant-Larios ${ }^{\mathrm{a}}$ Verónica Díaz-Hernández ${ }^{\mathrm{b}}$ Diego Cortez ${ }^{\mathrm{c}}$ \\ anstituto de Investigaciones Biomédicas, Departamento de Biología Celular y Fisiología, Universidad Nacional \\ Autónoma de México, Mexico city, Mexico; ${ }^{b}$ Facultad de Medicina, Departamento de Embriología, Universidad \\ Nacional Autónoma de México, Mexico city, Mexico; ' ${ }^{C}$ entro de Ciencias Genómicas, Universidad Nacional \\ Autónoma de México, Cuernavaca, Mexico
}

\section{Keywords}

Dmrt1 $\cdot$ Gonad $\cdot \mathrm{Kdm6b} \cdot$ Sox9 $\cdot$ Temperature-dependent sex determination

\begin{abstract}
The discovery in mammals that fetal testes are required in order to develop the male phenotype inspired research efforts to elucidate the mechanisms underlying gonadal sex determination and differentiation in vertebrates. A pioneer work in 1966 that demonstrated the influence of incubation temperature on sexual phenotype in some reptilian species triggered great interest in the environment's role as a modulator of plasticity in sex determination. Several chelonian species have been used as animal models to test hypotheses concerning the mechanisms involved in temperature-dependent sex determination (TSD). This brief review intends to outline the history of scientific efforts that corroborate our current understanding of the state-of-the-art in TSD using chelonian species as a reference.

(c) 2021 S. Karger AG, Basel
\end{abstract}

\section{Introduction}

Seven decades ago, Alfred Jost discovered that the fetal testes are necessary to initiate phenotypic sexual differentiation in eutherian mammals. Early castrated male and female rabbit fetuses with developed female internal and external organs indicated that the fetal testes produce 2 factors required to prevent the development of the constitutive female phenotype [Jost, 1947].

The author found that one of these factors was the steroid hormone testosterone, involved in both the development of the Wolffian ducts and the differentiation of the male urogenital sinus. The second factor was a still unknown chemical substance, which Jost named the Mullerian inhibiting hormone (MIH). Furthermore, the author proposed that a testis determining factor (TDF) produced in the early bipotential gonads preceded the onset of phenotypic sex differentiation in mammals [Jost, 1947]. These seminal experiments established the paradigm of our current research to elucidate the mechanisms involved in the process of sex determination in amniote vertebrates.

After the discovery of dimorphic sex chromosomes [Stevens, 1905; Wilson, 1905], research efforts undertaken by several laboratories culminated in the genetic factor 
sequence and physiological demonstration of the Sry gene as the TDF [Berta et al., 1990; Koopman et al., 1990, 1991; Lovell-Badge and Robertson, 1990; Sinclair et al., 1990], making it possible to elucidate both the genomic and the epigenomic mechanistic basis underlying the process of sex determination in diverse pluricellular animal taxa. Similarly, the effect that incubation temperature has on sex determination in the lizard Agama agama described by Madeleine Charnier [Charnier, 1966] initiated new research in developmental and evolutionary biology, the influence of the incubation temperature on phenotypic plasticity, and the evolution of sex determination systems among non-eutherian vertebrates.

Pioneer experimental approaches have used chelonian species as animal models to test various hypotheses to elucidate the mechanisms involved in temperaturedependent sex determination (TSD) [Pieau, 1970, 1971]. Furthermore, this, together with the most recent molecular mechanistic advances made by studying the red-eared turtle Trachemys scripta [Ge et al., 2017, 2018; Weber et al., 2020], reinforced our current interest in reviewing the state-of-the-art in TSD, using chelonian species as a reference (for a comprehensive review see online suppl. Table 1; see www.karger.com/doi/10.1159/515296 for online suppl. material).

The major subject of the current review is the temperature-sensitive period (TSP) in turtles. Because the molecular and cellular processes that sense the environmental temperature occur in the embryonic gonads, a correlation between developmental stages, gonadal morphogenesis, and spatiotemporal regulation of gene expression is presented. Moreover, we emphasize that the species diversity of processes underlying TSP occur in the sexually bipotential gonads with a highly conserved developmental pattern.

\section{Structural Changes during the Establishment of the Bipotential Gonad}

Although elucidation of the molecular mechanisms underlying the processes of TSD has advanced rapidly, understanding the cell-cell interactions that occur in the bipotential gonads remains important for our understanding of the temperature-dependent spatiotemporal regulation of gene networks during gonadal morphogenesis. Amniote vertebrates (reptiles, birds, and mammals) develop a structurally similar gonadal primordium, indicating that the morphogenetic factors involved in this process are conserved [Wibbels et al., 1991b, 1993; Merchant-Larios et al., 1997, 2010].
Interestingly, however, evolutionary studies indicate that the temporal regulation of key sex-determining genes differs between species, both in species with genotypic sex determination (GSD) and species that manifest TSD, as well as among the species from the 2 groups [Valenzuela et al., 2013; Mizoguchi and Valenzuela, 2020]. Thus, it appears that species-specific regulatory gene networks evolved in sexually bipotential gonads where a basic histological structure is conserved.

The establishment of the gonadal primordium initiates its developmental trajectory with the arrangement of 2 tissue compartments: (1) an epithelial tissue of tightly attached cells, forming both the surface epithelium and the medullary cords and, (2) the stromal tissue containing loosely organized cells formed by mesenchymal, fibroblasts, and blood vessels (Fig. 1). The formation of the genital ridges begins on the ventral side of the mesonephros to either side of the hindgut mesentery. Mesothelial cells proliferate and organize the early epithelial compartment, the medullary cords' precursor in the morphologically undifferentiated gonad. The stromal tissue around the early gonadal cords is shared with the stromal tissue adjacent to the dorsally located mesonephros. Both the epithelial and the stromal compartments in the gonadal ridge gradually become segregated by a basal membrane. Initially, a thin basal lamina, formed mainly by the protein laminin, is secreted by the epithelial cells, and subsequently, this inter-tissular boundary thickens with the addition of type IV collagen, secreted by the surrounding fibroblastic cells in the stromal tissue [Merchant-Larios et al., 1997].

As a developing biological system, the effect of temperature on the bipotential gonad in TSD species is a cumulative process. It occurs in the 2 basic tissular types mentioned above: epithelial and stromal (Fig. 1). Cells from these 2 tissues actively proliferate and differentiate as 2 heterogeneous populations, which eventually stabilize to form either a testis or an ovary. Thus, it remains an important research area to clearly define the molecular events that result in somatic and germ cell specification, epithelial-stromal tissue segregation, and ultimately "locking in" the fate of the bipotential gonad toward the irreversible structural differentiation of either an ovary or a testis.

As the embryonic developmental patterns of fresh water and marine turtles differ, 2 separate staging tables were developed. The ontogenetic changes of freshwater turtles are divided into 27 stages [Yntema, 1968], while the table used for marine turtles comprises 31 stages [Miller, 1985; Miller et al., 2017]. Thus, it is not surprising that the stages spanned by the TSP differ between these 2 groups (as they do within) (Table 1). Furthermore, at constant temperatures, the piv- 


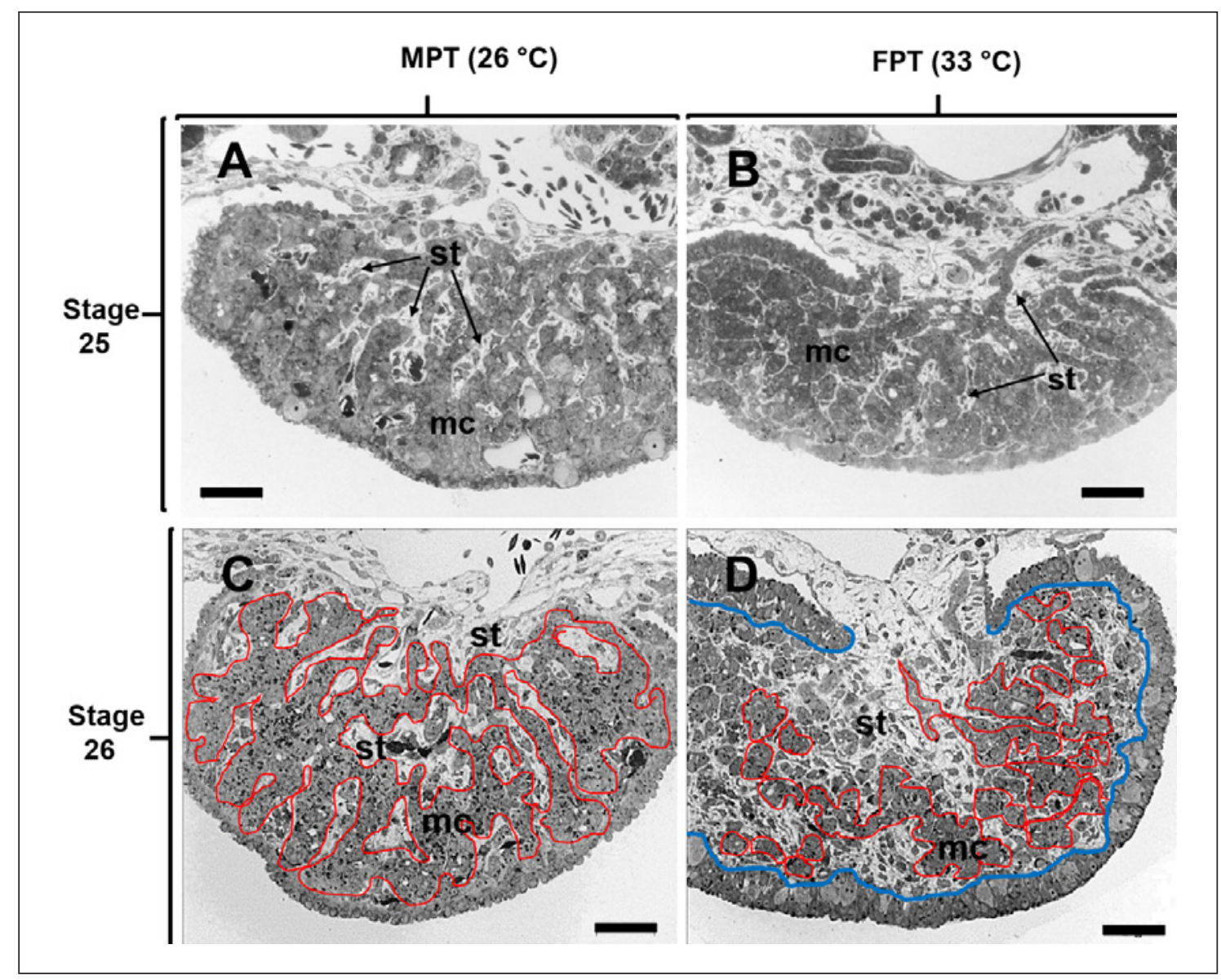

Fig. 1. Semi-thin sections $(1.0 \mu \mathrm{m})$ of olive ridley gonads stained with toluidine blue. A, B Bipotential gonads appear morphologically undifferentiated at stage 25 when embryos were incubated at either MPT or FPT. C, D The epithelial tissues of medullary cords (mc, red) and the ovarian surface epithelium (blue) highlight the stromal tissue (st) in early differentiated testis (C) and ovary (D) at stage 26 . Scale bars, $50 \mu \mathrm{m}$.

otal temperature (PT), which produces $50 \%$ of each sex, and the transitional range of temperatures (TRT), which include temperatures that are not either fully masculinizing or fully feminizing [Pieau and Mrosovsky, 1991], also differ within species (populations) and between species. For example, although in most sea turtles, the PT is around $29^{\circ} \mathrm{C}$, in Lepidochelys olivacea, also a sea turtle, the PT is close to $30.5^{\circ} \mathrm{C}$ [Wibbels et al., 1998].

The red-eared turtle T. scripta became the most studied model system for analyzing the molecular mechanisms underlying TSD in reptiles. Temperature shift experiments ascertained the developmental stages during the TSP, and such experiments that involved transferring eggs from a female-producing (FPT) to a male-producing (MPT) temperature (or vice versa) helped identify the developmental stages that comprise the TSP. This was un- dertaken at different times during incubation, and then it was examined whether the resulting sex ratios corresponded to the initial temperature (indicating that the TSP had concluded by the time of transfer) or to the second temperature (indicating that the TSP had not initiated at the time of transfer).

Wibbels et al. [1991a] used single-shift experiments in T. scripta between a MPT $\left(26^{\circ} \mathrm{C}\right)$ and a FPT $\left(31^{\circ} \mathrm{C}\right)$ as well as double-shift experiments (incubating eggs at the MPT and exposing groups to a pulse of the FPT of increasing duration - or vice versa). Based on the resulting sex ratios and using Yntema's developmental table [Yntema, 1968], Wibbels et al. [1991a] concluded that the TSP of T. scripta occurs between stages 16-20 (Table 1). Histological differentiation is evident at stages 20/21 (Table 1) [Wibbels et al., 1991b; Ramsey et al., 2007]. 
Table 1. Equivalent stages of embryonic development from fresh water and marine turtles.

\begin{tabular}{|c|c|c|c|}
\hline \multicolumn{2}{|c|}{$\begin{array}{l}\text { Fresh water turtles ( } 27 \text { stages) } \\
\text { [Yntema, 1968; Greenbaum, } \\
\text { 2002] }\end{array}$} & \multicolumn{2}{|c|}{$\begin{array}{l}\text { Marine turtles (31 stages) } \\
\text { [Miller, 1985; Miller et al., } \\
\text { 2017] }\end{array}$} \\
\hline Stage & $\begin{array}{l}\text { Duration, } \\
\text { days }\end{array}$ & Stage & $\begin{array}{l}\text { Duration, } \\
\text { days }\end{array}$ \\
\hline $14^{*}$ & $3.80 \pm 1.49$ & $21^{*}$ & 2.0 \\
\hline $15^{*}$ & $3.71 \pm 1.04$ & $22^{*}$ & 2.0 \\
\hline $16^{*}$ & $3.77 \pm 0.99$ & 23 & 2.0 \\
\hline 17 & $3.88 \pm 1.01$ & 24 & 2.0 \\
\hline 18 & $3.76 \pm 0.99$ & 25 & 4.2 \\
\hline 19 & $4.35 \pm 1.71$ & 26 & 4.2 \\
\hline 20 & $4.90 \pm 1.86$ & 27 & 4.9 \\
\hline
\end{tabular}

Data are shown at the establishment of the bipotential gonad $\left.{ }^{*}\right)$ and through the temperature-sensitive period (TSP) (bold numbers). Duration corresponds to eggs incubated at constant temperatures of 27 and $29^{\circ} \mathrm{C}$ in fresh water and marine turtles; respectively. However, the duration differs considerably depending on the incubation temperature. Temperature shift experiments from either a female-producing (FPT) to a male-producingtemperature (MPT) $\left(26 \rightarrow 31^{\circ} \mathrm{C}\right.$, or vice versa $\left(31 \rightarrow 26^{\circ} \mathrm{C}\right)$ in $T$. scripta showed that the TSP occurs at stages 16-20 [Wibbels et al., 1991a], whereas in L. olivacea, shift experiments were from $33 \rightarrow 26^{\circ} \mathrm{C}$ or vice versa and the TSP occurs at stages 23-25 [DíazHernández et al., 2019b]

Gene networks involved in sex determination are gradually expressed in morphologically undifferentiated gonads throughout several developmental stages. Shift experiments indicated that during early stages, all gonads responded to the shifted temperature. During intermediate stages, some failed to respond. Finally, none of them responded during the later stages when gonads are still histologically undifferentiated. Sexual determination occurs prior to the differentiation of testis or ovary. The gonads of embryos develop in a similar way during early stages. They are not sexually committed, regardless of the initial incubation temperature. Thus, if irreversible sexual commitment equals sexual determination, the TSP is shorter than so far assumed.

\section{Dimorphic Estrogen Levels for Temperature- Dependent Sex Determination}

Three turtles, Testudo graeca, Emys orbicularis, and Dermochelys coriacea, were used in the first steroid hormone experiments to elucidate the mechanisms in TSD.
Results strongly suggested a correlation between estrogen levels, the incubation temperature of the eggs, and ovarian differentiation during the TSP [Pieau, 1970, 1974]. Most embryos differentiated ovaries when treated with exogenous estrogens at MPT. They formed testis when antiestrogens or aromatase inhibitors were administered at FPT [Richard-Mercier et al., 1995]. Similar results were obtained in other species such as T. scripta [Wibbels et al., 1991b; Crews and Bergeron, 1994] and Chelydra serpentina [Rhen and Lang, 1994]. Thus, it was proposed that temperature regulation of the aromatase gene Cyp19a1, the enzyme that transforms testosterone to estradiol, plays a key role in the first steps of ovarian differentiation and probably in sex determination [Pieau and Dorizzi, 2004].

However, further results using different protocols of $3 \beta$-estradiol and aromatase inhibitors in turtles weakened the aromatase hypothesis as the upstream key factor for TSD. Although the expression of Cyp19a1 is higher in gonads of embryos incubated at FPT than at MPT, treatment with exogenous $\beta$-estradiol or aromatase inhibitors at MPT or FPT, respectively, rarely mimic the normal process of ovarian differentiation [Merchant-Larios et al., 1997; Barske and Capel, 2010; Bieser and Wibbels, 2014; Díaz-Hernández et al., 2015, 2017].

Overall, results from $T$. scripta showed that $17 \beta$-estradiol treatments and aromatase inhibitors reduce gonadal size [Dodd and Wibbels, 2008; Barske and Capel, 2010] or even curtail gonadal development [Bieser and Wibbels, 2014], as was previously reported for the sea turtle L. olivacea [Merchant-Larios et al., 1997]. At the cellular level, the altered establishment of the bipotential gonads was due to a significant decrease in the proliferation rate in medullary cords cells. Thus, the exogenous treatments of hormones cause a conflict between the timing of expression of the temperature-dependent gene networks and the sexually dimorphic levels of endogenous estrogens [Díaz-Hernández et al., 2015, 2017]. As a result, the complex morphogenetic results obtained by manipulating the endogenous steroid levels during the TSP led to regarding aromatase as a key downstream component of a larger gene regulatory network in the female pathway. The identification of the upstream gene/s involved in the regulation of Cyp19a1 became the next research goal.

\section{Search for Temperature-Dependent Gene Networks}

Research on the snapping turtle, C. serpentina, suggested that in embryos incubated at FPT, the gonadal expression of Cyp19a1 may be regulated by Foxl2. Thus, the 
positive feedback of aromatase stimulates ovarian differentiation [Ramsey et al., 2007]. Foxl2 displays a temperature-dependent expression pattern during the TSP with higher expression occurring at FPT than at MPT. It was unclear whether Foxl2 was a key regulator for ovarian differentiation in T. scripta. However, sex-reversing temperature shift experiments suggested that Foxl2 was an important factor to settle ovarian differentiation [Shoemaker et al., 2007b]. Further studies showed that Foxl2 and Cyp19a1 are expressed in bipotential gonads but become sexually dimorphic after the TSP, suggesting a possible role in bipotential gonads and the maintenance of differentiated ovaries [Bieser and Wibbels, 2014].

The dimorphic regulation of the Sox9 gene rendered it another candidate sex-determining gene among turtles with TSD. After sequencing and physiological validation of the Sry gene as the previously elusive TDF [Koopman et al., 1990], it was found that this transcription factor acted only as a transitory switch to upregulate Sox 9 in eutherian mammals [Koopman et al., 1990, 1991; Morais da Silva et al., 1996]. Furthermore, it was revealed that in contrast to the Sry gene, which is located on the short arm of the Y chromosome, Sox 9 is autosomal in mammals and is necessary for both differentiation and maintenance of Sertoli cells [Sekido and Lovell-Badge, 2008; Uhlenhaut et al., 2009; Matson et al., 2011]. Thus, Sox9 expression plays a key role in testis morphogenesis and function of the postnatal testes.

Interestingly, Sertoli cells of all amniote vertebrates express Sox9 protein, regardless of their sex-determination system (XY, ZW, or TSD) [Morais da Silva et al., 1996]. In contrast to eutherian mammals, the medullary cords of early bipotential gonads in turtles express Sox 9 protein before temperature-dependent Sertoli cell specification [Spotila et al., 1998; Moreno-Mendoza et al., 1999; Ramsey et al., 2007; Shoemaker et al., 2007a; Barske and Capel, 2010]. Thus, the sex fate of bipotential gonads to differentiate as either testes or ovaries depends on the upstream mechanism(s) that maintain upregulated Sox9 in the cells of the medullary cords that become the testis cords at MPT. In both the freshwater turtle T. scripta [Shoemaker et al., 2007a; Barske and Capel, 2010; Bieser and Wibbels, 2014] and the sea turtle L. olivacea [Torres Maldonado et al., 2002; Díaz-Hernández et al., 2019b], the surface epithelium is Sox9 negative; however, in the sea turtle, an area of Sox9-expressing mesothelial cells, located on either side of the hindgut mesentery, precedes the formation of the genital ridges [Díaz-Hernández et al., 2012].

Subsequently, Sox9-expressing mesothelial cells proliferate asymmetrically. Those facing the coelomic cavity turn off Sox9, whereas cells that form the medullary cords maintain Sox9 expression; thus, the 2 tissue compartments of the bipotential gonad are established [DíazHernández et al., 2012]. Temperature shift experiments suggest that modulation of gene networks underlying sex determination occurs in a highly proliferating heterogeneous population that is gradually specified [DíazHernández et al., 2017].

Most studies in reptilian species at the molecular level, including turtles with TSD, explored orthologs of mouse sex-determining genes [Rhen and Schroeder, 2010]. In the fast-developing bipotential mouse gonads, a clear distinction between cortex and medullary regions is rarely visible; however, the 2 regions are evident in most mammalian species [Díaz-Hernández et al., 2019a]. As most physiological validation of genes and gene networks involved in mammalian sex determination employed murine gonads, the role played by the sex dimorphic regulation of gene expression in terms of the 2 classical gonadal regions in the Amniote vertebrates [Witschi, 1951] has seldom been considered.

Recent studies in gonads of the marine turtle L. olivacea revealed the spatiotemporal expression pattern of Sox9, Dmrt1, and Foxl2, 3 key transcription factors underlying TSD during the TSP [Díaz-Hernández et al., $2019 b]$. Our results showed that in early bipotential gonads, cells of the medullary cords express Sox9 at both MPT and FPT up to stage 24. At this stage, Dmrtl protein starts being detected in some medullary cells at both temperatures (Fig. 2a). Then, cells of the medullary cords express Foxl2 at stage 25 in embryos incubated at FPT (Fig. 2b). Up to this stage, the medullary cords are similar and Sox9 remains expressed regardless of incubation temperature. Morphological differentiation (early ovary or testis) occurs at stage 26 . Here the medullary cords maintain Sox9 and Dmrt1, while Sox9 is turned off and Foxl2 expresses in medullary cells establishing the ovarian fate (Fig. 1d, 2b) [Díaz-Hernández et al., 2019b]. Thus, the TSP in L. olivacea occurs in the asynchronous medullary cell population and lasts around 8 days (Table 1).

A study in T. scripta explored the transcriptome of the developing gonad at MPT and FPT $\left(26\right.$ and $31^{\circ} \mathrm{C}$, respectively). Relevant genes [Czerwinski et al., 2016] showed differential expression patterns based on incubation temperature. The gene Dmrt1 is particularly important, because it codes for a transcription factor that regulates testis development in T. scripta [Ge et al., 2017] and many other vertebrates. Moreover, also in T. scripta, Dmrt1 and Sox9 seem to mediate the activation of Amh and the repression of aromatase [Czerwinski et al., 2016]. Similarly, 


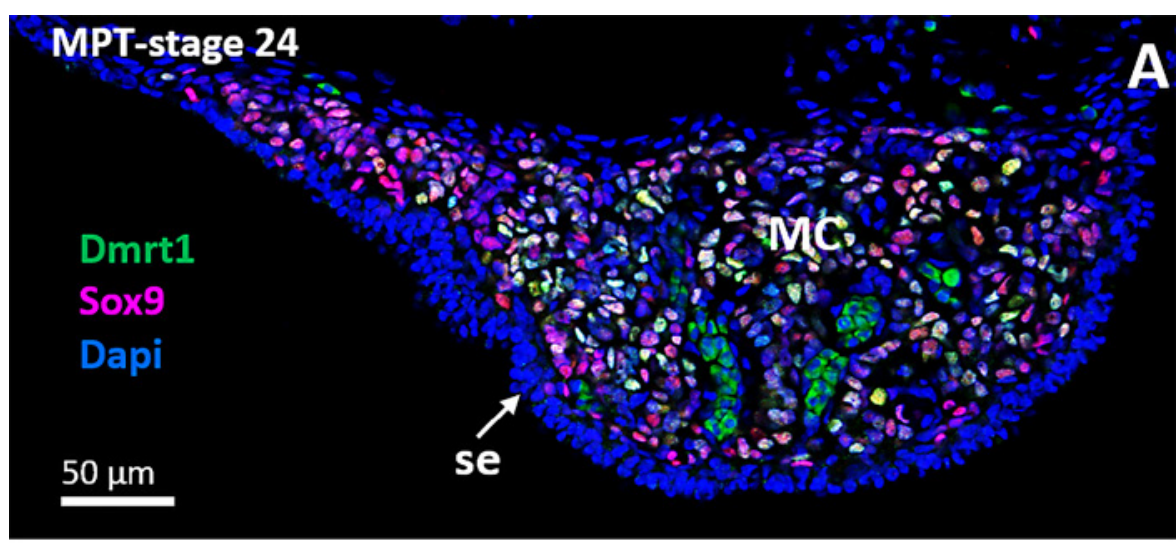

Fig. 2. Immunofluorescent detection of Sox9, Dmrt1, and Foxl2 proteins in bipotential gonads of L. olivacea. A. Stage 24 incubated at MPT. Cells in the medullary cords (MC) show nuclei with Dmrt1 (green), Sox9 (pink), and colocalized Dmrt1 and Sox9 (yellow). Note the absence of these 3 proteins in cells of the surface epithelium (se). B. Stage 25 incubated at FPT. Cell nuclei of medullary cords show Foxl2 in the histologically still undifferentiated gonads. The upper rectangle corresponds to the lower white dashed area. Foxl2 appears light blue or green with or without Dapi staining, respectively. Epithelial cells are marked with cytokeratin (pink).

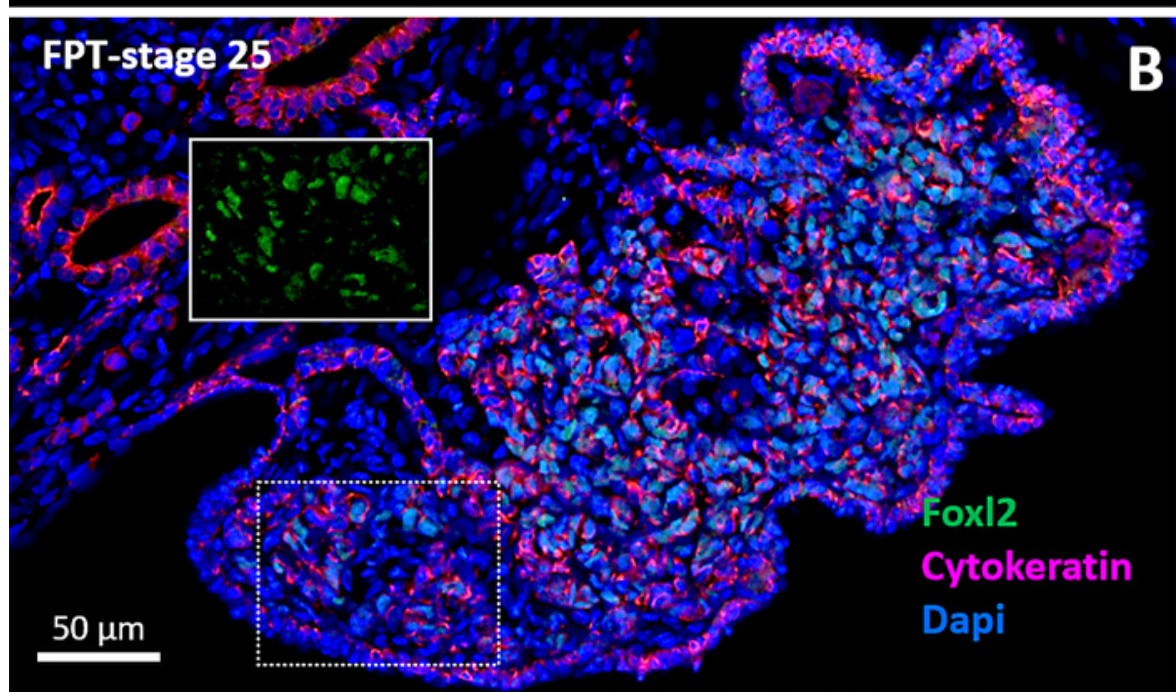

in another freshwater turtle, the soft-shelled Pelodiscus sinensis, Dmrt1 also induces the expression of Amh and Sox9 but inhibits the ovary-related gene Foxl2 [Sun et al., 2017].

\section{Epigenetic Approach}

Understanding the epigenetic mechanism(s) involved in transducing environmental temperature variation became the next research priority: firstly, in order to elucidate how thermal signals are transduced into transitory (reversible) responses of gene networks in bipotential gonads during the TSP and then into stabilized (irreversible) gene networks involved in testis or ovarian differentiation. As usually occurred with TSD species, the first epigenetic studies were correlative. Marks in DNA and histone modifications were found in T. scripta [Matsumoto et al., 2013] and the olive ridley L. olivacea [Venegas et al., 2016], respectively. After that, in the past few years, some studies have made significant contributions toward describing the first important players in the TSD pathway.

Among the genes that show differential expression in the T. scripta gonads, $K d m 6 b$, a [Histone H3]-trimethyl-L-lysine 27 demethylase $6 \mathrm{~B}$, acts as a transcription activator and caught the attention of researchers. In a relevant study [Ge et al., 2018], the researchers managed to perform gene knockdowns in living turtle embryos. In this work, the knockdown of $K d m 6 b$ triggered a male-tofemale sex reversal at MPT. It was also apparent that the $\mathrm{Kdm} 6 \mathrm{~b}$ protein binds the promoter region of the Dmrt1 locus and activates its transcription [Ge et al., 2018] thus directing the gonad toward testis development. Additionally, $K d m 6 b$ expression levels were directly inhibited by the transcription repressor $p S t a t 3$, which at $32^{\circ} \mathrm{C}$ becomes phosphorylated due to increased levels of intracellular $\mathrm{Ca}^{2+}$ [Weber et al., 2020] (Fig. 3). Kdm6b is a member of the Jumonji family of chromatin modifiers. Interestingly, placental mammals carry the [Histone $\mathrm{H} 3$ ]-trimethyl-L-lysine 27 demethylase 6A (Kdm6a; also 


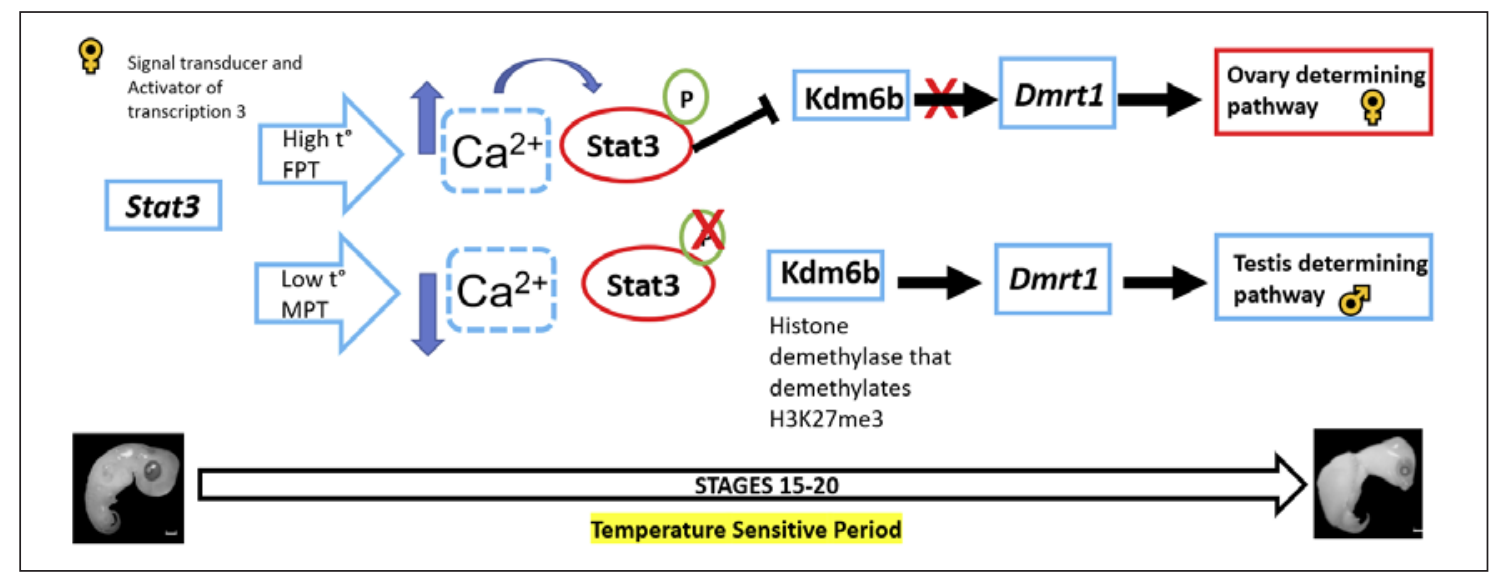

Fig. 3. A molecular model of TSD based on Weber et al. [2020]. Higher calcium levels at $31^{\circ} \mathrm{C}$ (FPT) promote Stat3 phosphorylation, which represses Kdm6b transcription, a required activator for Dmrt1 expression.

known as UTX/UTY) on their sex chromosomes; UTY is one of the very few Y-linked genes conserved across the major groups of placental mammals [Martínez-Pacheco et al., 2020]. Moreover, another Jumonji family member, $J m j d 1 a$, is a direct regulator of the mammalian sex-determining factor Sry in mice [Kuroki et al., 2013].

Remarkably, Kdm6b exhibits temperature-dependent alternative splicing such that at MPT it retains intron 19 [Deveson et al., 2017], resulting in a truncated protein lacking the last exon. Temperature-dependent alternative splicing of $K d m 6 b$ has been reported in 3 species of reptiles: T. scripta, the American alligator Alligator mississippiensis, and the acrodont Pogona vitticeps [Deveson et al., 2017]. However, it is unclear whether these temperaturedependent alternative isoforms represent the ancestral state in reptiles or are a beautiful example of convergent evolution. Likewise, we still do not know the potential function of these temperature-dependent isoforms. At $26^{\circ} \mathrm{C}$, where $K d m 6 b$ activates $D m r t 1$ [Ge et al., 2018], the most common isoform appears to be the one lacking the last exon [Deveson et al., 2017].

Another member of the Jumonji family of chromatin modifiers, Jarid2, follows a similar pattern of temperature-dependent splicing [Deveson et al., 2017]. A complete protein is observed at FPT, whereas at MPT, an alternative isoform is detected, showing intron retention that contains a premature stop codon that produces a truncated isoform, lacking the last 2 exons and a zinc finger DNA-binding domain [Deveson et al., 2017]. Jarid2 is a transcriptional repressor that acts together with the Polycomb Repressive Complex 2 (PRC2), which is capable of tri-methylating histone $\mathrm{H} 3$ on lysine 27
(H3K27me3) and produces transcriptionally silent chromatin [da Rocha et al., 2014; Kaneko et al., 2014; Sanulli et al., 2015]. Nevertheless, there is no evidence of Jarid2 playing a role in sex determination. A recent study found that phosphorylated CLK kinases that regulate circadian rhythms in humans [Haltenhof et al., 2020] can sense slight temperature changes. Interestingly, in T. scripta, these kinases promote the intron retention of Jarid2 at $26^{\circ} \mathrm{C}$ [Haltenhof et al., 2020].

As mentioned above, the epigenetic upregulation of Dmrt1 underlies testis determination and Foxl2 establishes the ovarian fate of bipotential gonads in T. scripta. Let us suppose that the same histological mechanism of TSD is conserved in L. olivacea. This being the case, our study to localize Dmrt1 and Fox2 [Díaz-Hernández et al., 2019b] indicates that temperature-dependent sex fate is a gradual process that occurs in the medullary cords during the TSP (Fig. 2); however, conservation cannot be assumed. In fact, Dmrtl regulation varies between the closely related TSD turtles T. scripta and Chrysemys picta [Mizoguchi and Valenzuela, 2020], and Dmrt1 expression in C. picta indicates that this takes place further downstream in the sex determination process than it does in T. scripta and that extensive transcriptional evolution has occurred among vertebrates.

\section{Conclusion}

As outlined above, the quest to elucidate the cellular and molecular mechanism underlying TSD in bipotential turtle gonads has made steady progress. Thanks to outstanding technological advances, the original challenge of 
an essentially mysterious and fascinating problem is now gradually arriving at reliable answers. However, many questions still lack a clear answer. At the cellular level, we have still not identified the gene networks conserved during evolution that underlie the establishment of the bipotential gonads and transitory gene networks involved in the morphogenetic process that leads to their transformation into ovary or testis. Several questions remain at the molecular level: what are the function of Jarid2 and $K d m 6 b$ temperature-dependent alternative isoforms? Is Jarid 2 also involved in the TSD pathway? Does Dmrt1 or $K d m 6 b$ inhibit specific targets in the ovarian development pathway? What are the genetic targets of Amh and Sox9? What are the factors inhibiting Dmrt1 transcription at FPT? Do CLK kinases directly control the alternative splicing of Jarid 2 and that of $K d m 6 b$ ? Do major gene expression changes take place following behavioral thermoregulation by turtle embryos [Ye et al., 2019]?

\section{Acknowledgments}

The authors acknowledge Alejandro Marmolejo-Valencia, Miguel Tapia Rodríguez, and Paloma Domínguez Mora.

\section{Conflict of Interest Statement}

The authors have no conflicts of interest to declare.

\section{Funding Sources}

This study was supported by Programa de Apoyo a Proyectos de Investigación e Innovación Tecnológica PAPIIT-UNAM IN201218, IN216717, IN209520, and FORDECYT-PRONAC$\mathrm{ES} / 137721 / 2020$.

\section{Authors Contributions}

All authors drafted and provided critical revision of the article.

\section{References}

Barske LA, Capel B. Estrogen represses SOX9 during sex determination in the red-eared slider turtle Trachemys scripta. Dev Biol. 2010;341(1):305-14.

Berta P, Hawkins JR, Sinclair AH, Taylor A, Griffiths BL, Goodfellow PN, et al. Genetic evidence equating SRY and the testis-determining factor. Nature. 1990;348(6300):448-50.

Bieser KL, Wibbels T. Chronology, magnitude and duration of expression of putative sexdetermining/differentiation genes in a turtle with temperature-dependent sex determination. Sex Dev. 2014;8(6):364-75.

Crews D, Bergeron JM. Role of reductase and aromatase in sex determination in the red-eared slider (Trachemys scripta), a turtle with temperature-dependent sex determination. J Endocrinol. 1994;143(2):279-89.

Czerwinski M, Natarajan A, Barske L, Looger LL, Capel B. A timecourse analysis of systemic and gonadal effects of temperature on sexual development of the red-eared slider turtle Trachemys scripta elegans. Dev Biol. 2016; 420(1):166-77.

Charnier M. Action of temperature on the sex ratio in the Agama agama (Agamidae, Lacertilia) embryo. C R Seances Soc Biol Fil. 1966; 160(3):620-2.

da Rocha ST, Boeva V, Escamilla-Del-Arenal M, Ancelin K, Granier C, Matias NR, et al. Jarid2 is implicated in the initial Xist-induced targeting of PRC2 to the inactive X chromosome. Mol Cell. 2014;53(2):301-16.
Deveson IW, Holleley CE, Blackburn J, Marshall Graves JA, Mattick JS, Waters PD, et al. Differential intron retention in Jumonji chromatin modifier genes is implicated in reptile temperature-dependent sex determination. Sci Adv. 2017;3(6):e1700731.

Díaz-Hernández V, Marmolejo-Valencia A, Harfush M, Merchant-Larios H. Formation of the genital ridges is preceded by a domain of ectopic Sox9-expressing cells in Lepidochelys olivacea. Dev Biol. 2012;361(1):156-66.

Díaz-Hernández V, Marmolejo-Valencia A, Merchant-Larios H. Exogenous estradiol alters gonadal growth and timing of temperature sex determination in gonads of sea turtle. Dev Biol. 2015;408(1):79-89.

Díaz-Hernández V, Vázquez-Gómez A, Marmolejo-Valencia A, Montaño LM, MerchantLarios H. 17 $\beta$-Estradiol modulates cell proliferation of medullary cords during ovarian differentiation of the Lepidochelys olivacea sea turtle. Dev Biol. 2017;431(2):263-71.

Díaz-Hernández V, Caldelas I, Merchant-Larios $\mathrm{H}$. Gene expression in the supporting cells at the onset of meiosis in rabbit gonads. Sex Dev. 2019a;13(3):125-36.

Díaz-Hernández V, Dominguez-Mora $\mathrm{P}$, ChinoPalomo L, Marmolejo-Valencia A, Harfush M, Merchant-Larios H. Spatiotemporal expression of Foxl2 and Dmrt1 before, during, and after sex determination in the sea turtle Lepidochelys olivacea. Sex Dev. 2019b;13: 286-96.
Dodd KL, Wibbels T. Estrogen inhibits caudal progression but stimulates proliferation of developing müllerian ducts in a turtle with temperature-dependent sex determination. Comp Biochem Physiol, Part A Mol Integr Physiol. 2008;150(3):315-9.

Ge C, Ye J, Zhang H, Zhang Y, Sun W, Sang Y, et al. Dmrtl induces the male pathway in a turtle species with temperature-dependent sex determination. Development. 2017; 144(12): 2222-33.

Ge C, Ye J, Weber C, Sun W, Zhang H, Zhou Y, et al. The histone demethylase KDM6B regulates temperature-dependent sex determination in a turtle species. Science. 2018; 360(6389):645-8.

Haltenhof T, Kotte A, De Bortoli F, Schiefer S, Meinke S, Emmerichs AK, et al. A conserved kinase-based body-temperature sensor globally controls alternative splicing and gene expression. Mol Cell. 2020;78(1):57-e4.

Jost A. Reserches sur la différenciation sexuelle de l'embryon de lapin. Arch Anat Microsc Morphol Exp. 1947;36:271-315.

Kaneko S, Bonasio R, Saldaña-Meyer R, Yoshida $\mathrm{T}$, Son J, Nishino K, et al. Interactions between JARID2 and noncoding RNAs regulate PRC2 recruitment to chromatin. Mol Cell. 2014;53(2):290-300.

Koopman P, Münsterberg A, Capel B, Vivian N, Lovell-Badge R. Expression of a candidate sex-determining gene during mouse testis differentiation. Nature. 1990;348(6300):4502. 
Koopman P, Gubbay J, Vivian N, Goodfellow P, Lovell-Badge R. Male development of chromosomally female mice transgenic for Sry. Nature. 1991;351(6322):117-21.

Kuroki S, Matoba S, Akiyoshi M, Matsumura Y, Miyachi H, Mise N, et al. Epigenetic regulation of mouse sex determination by the histone demethylase Jmjdla. Science. 2013; 341(6150):1106-9.

Lovell-Badge R, Robertson E. XY female mice resulting from a heritable mutation in the primary testis-determining gene, Tdy. Development. 1990;109(3):635-46.

Martínez-Pacheco M, Tenorio M, Almonte L, Fajardo V, Godínez A, Fernández D, et al. Expression evolution of ancestral XY gametologs across all major groups of placental mammals. Genome Biol Evol. 2020;12(11): 2015-28.

Matson CK, Murphy MW, Sarver AL, Griswold MD, Bardwell VJ, Zarkower D. DMRT1 prevents female reprogramming in the postnatal mammalian testis. Nature. 2011;476(7358): 101-4.

Matsumoto Y, Buemio A, Chu R, Vafaee M, Crews D. Epigenetic control of gonadal aromatase (cyp19a1) in temperature-dependent sex determination of red-eared slider turtles. PloS One. 2013;8(6):e63599.

Merchant-Larios H, Ruiz-Ramirez S, MorenoMendoza N, Marmolejo-Valencia A. Correlation among thermosensitive period, estradiol response, and gonad differentiation in the sea turtle Lepidochelys olivacea. Gen Comp Endocrinol. 1997;107(3):373-85.

Merchant-Larios H, Díaz-Hernández V, Marmolejo-Valencia A. Gonadal morphogenesis and gene expression in reptiles with temperature-dependent sex determination. Sex Dev. 2010;4(1-2):50-61.

Miller JD. Emryology of marine turtles. In: Gans C, Billet F (eds). Biology of the Reptilia. New York: Wiley-Interscience; 1985. p. 269-328.

Miller JD, Mortimer JA, Limpus CJ. A field key to the developmental stages of marine turtles (Cheloniidae) with notes on the development of dermochelys. Chelonian Conserv Biol. 2017; 16:111-112

Mizoguchi B, Valenzuela N. Alternative splicing and thermosensitive expression of Dmrt1 during urogenital development in the painted turtle, Chrysemys picta. PeerJ. 2020;8:e8639.

Morais da Silva S, Hacker A, Harley V, Goodfellow P, Swain A, Lovell-Badge R. Sox9 expression during gonadal development implies a conserved role for the gene in testis differentiation in mammals and birds. Nat Genet. 1996;14(1):62-8.

Moreno-Mendoza N, Harley VR, Merchant-Larios H. Differential expression of SOX9 in gonads of the sea turtle Lepidochelys olivacea at male- or female-promoting temperatures. J Exp Zool. 1999;284(6):705-10.

Pieau C. Effects of estradiol on the genital apparatus of the embryo of the Mauresque turtle (Testudo graceca L.). Arch Anat Microsc Morphol Exp. 1970;59(4):295-318.
Pieau C. Sex ratio in the embryos of 2 chelonians (Testudo graeca L. and Emys orbicularis L.) born of artificially incubated ova. CR Hebd Seances Acad Sci, Ser D, Sci Nat. 1971; 272(24):3071-4.

Pieau C. Différenciation du sexe en fonction de la température chez les embryons d'Emys orbicularis L. (Chélonien); effets des hormones sexuelles. Ann Embryol Morphog. 1974;7: 365-94.

Pieau C, Dorizzi M. Oestrogens and temperaturedependent sex determination in reptiles: all is in the gonads. J Endocrinol. 2004;181(3):36777.

Pieau C, Mrosovsky N. Transitional range of temperature, pivotal temperatures and thermosensitive stages for sex determination in reptiles. Amphib Reptilia. 1991;12(2):169-79.

Ramsey M, Shoemaker C, Crews D. Gonadal expression of Sf1 and aromatase during sex determination in the red-eared slider turtle (Trachemys scripta), a reptile with temperature-dependent sex determination. Differentiation. 2007;75(10):978-91.

Rhen T, Lang JW. Temperature-dependent sex determination in the snapping turtle: manipulation of the embryonic sex steroid environment. Gen Comp Endocrinol. 1994;96(2): 243-54.

Rhen T, Schroeder A. Molecular mechanisms of sex determination in reptiles. Sex Dev. 2010; 4(1-2):16-28.

Richard-Mercier N, Dorizzi M, Desvages G, Girondot M, Pieau C. Endocrine sex reversal of gonads by the aromatase inhibitor Letrozole (CGS 20267) in Emys orbicularis, a turtle with temperature-dependent sex determination. Gen Comp Endocrinol. 1995;100(3):314-26.

Sanulli S, Justin N, Teissandier A, Ancelin K, Portoso $\mathrm{M}$, Caron $\mathrm{M}$, et al. Jarid2 methylation via the PRC2 complex regulates H3K27me3 deposition during cell differentiation. Mol Cell. 2015;57(5):769-83.

Sekido R, Lovell-Badge R. Sex determination involves synergistic action of SRY and SF1 on a specific Sox9 enhancer. Nature. 2008; 453(7197):930-4.

Shoemaker C, Ramsey M, Queen J, Crews D. Expression of Sox9, Mis, and Dmrt1 in the gonad of a species with temperature-dependent sex determination. Dev Dyn. 2007a;236(4): 1055-63.

Shoemaker CM, Queen J, Crews D. Response of candidate sex-determining genes to changes in temperature reveals their involvement in the molecular network underlying temperature-dependent sex determination. Mol Endocrinol. 2007b;21(11):2750-63.

Sinclair AH, Berta P, Palmer MS, Hawkins JR, Griffiths BL, Smith MJ, et al. A gene from the human sex-determining region encodes a protein with homology to a conserved DNAbinding motif. Nature. 1990;346(6281):240-4.

Spotila LD, Spotila JR, Hall SE. Sequence and expression analysis of WT1 and Sox9 in the redeared slider turtle, Trachemys scripta. J Exp Zool. 1998;281(5):417-27.
Stevens N. Studies in Spermatogenesis with Special Reference to the 'Accessory Chromosomes'. Washington:Carnegie Institution of Washington; 1905.

Sun W, Cai H, Zhang G, Zhang H, Bao H, Wang $\mathrm{L}$, et al. Dmrtl is required for primary male sexual differentiation in Chinese soft-shelled turtle Pelodiscus sinensis. Sci Rep. 2017;7(1): 4433.

Torres Maldonado LC, Landa Piedra A, Moreno Mendoza N, Marmolejo Valencia A, Meza Martínez A, Merchant Larios H. Expression profiles of Dax1, Dmrt1, and Sox9 during temperature sex determination in gonads of the sea turtle Lepidochelys olivacea. Gen Comp Endocrinol. 2002;129(1):20-6.

Uhlenhaut NH, Jakob S, Anlag K, Eisenberger T, Sekido R, Kress J, et al. Somatic sex reprogramming of adult ovaries to testes by FOXL2 ablation. Cell. 2009;139(6):1130-42.

Valenzuela N, Neuwald JL, Literman R. Transcriptional evolution underlying vertebrate sexual development. Dev Dyn. 2013;242(4): 307-19.

Venegas D, Marmolejo-Valencia A, ValdesQuezada C, Govenzensky T, Recillas-Targa F, Merchant-Larios H. Dimorphic DNA methylation during temperature-dependent sex determination in the sea turtle Lepidochelys olivacea. Gen Comp Endocrinol. 2016;236: 35-41.

Weber C, Zhou Y, Lee JG, Looger LL, Qian G, Ge $\mathrm{C}$, et al. Temperature-dependent sex determination is mediated by pSTAT3 repression of Kdm6b. Science. 2020;368(6488):303-6.

Wibbels T, Bull JJ, Crews D. Chronology and morphology of temperature-dependent sex determination. J Exp Zool. 1991a;260(3):37181.

Wibbels T, Bull JJ, Crews D. Synergism between temperature and estradiol: a common pathway in turtle sex determination? J Exp Zool. 1991b;260(1):130-4.

Wibbels T, Gideon P, Bull JJ, Crews D. Estrogenand temperature-induced medullary cord regression during gonadal differentiation in a turtle. Differentiation. 1993;53(3):149-54.

Wibbels T, Rostal D, Byles R. High pivotal temperature in the sex determination of the olive ridley sea turtle, Lepidochelys olivacea, from Playa Nancite, Costa Rica. Copeia. 1998; 1998(4): 1086.

Wilson EB. The chromosomes in relation to the determination of sex in insects. Science. 1905; 22(564):500-2.

Witschi E. Embryogenesis of the adrenal and the reproductive glands. Recent Prog Horm Res. 1951;6:1-27.

Ye YZ, Ma L, Sun BJ, Li T, Wang Y, Shine R, et al. The embryos of turtles can influence their own sexual destinies. Curr Biol. 2019;29(16): 2597e2594-e4.

Yntema CL. A series of stages in the embryonic development of Chelydra serpentina. J Morphol. 1968;125(2):219-51. 